\title{
Physical characterization of Rhipsalis (Cactaceae) fruits and seeds germination in different temperatures and light regimes
}

\author{
A. B. Lone ${ }^{a}$, R. C. Colombo ${ }^{a *}$, B. L. G. Andrade ${ }^{a}$, L. S. A. Takahashi ${ }^{a}$ and R. T. Faria ${ }^{a}$ \\ a Departamento de Agronomia, Universidade Estadual de Londrina - UEL, \\ Rodovia Celso Garcia Cid, PR 445, Km 380, CP 6001, CEP 86051-990, Londrina, PR, Brazil \\ *e-mail: ronancolombo@yahoo.com.br
}

Received: August 11, 2014 - Accepted: July 9, 2015 - Distributed: May 31, 2016

(With 1 figure)

\begin{abstract}
The germination characteristics of the native cactus species are poorly known, being the temperature and the light the factors that the most interferes in that process. Thus, the objective of the present work was to characterize the fruits and evaluate the influence of the temperature and the light in the seed germination of Rhipsalis floccosa, Rhipsalis pilocarpa and Rhipsalis teres. The tested constant temperatures were $15,20,25,30$ and $35{ }^{\circ} \mathrm{C}$ and the alternate of $20-30{ }^{\circ} \mathrm{C}$ and $25-35^{\circ} \mathrm{C}$ in a photoperiod of 10 hours, and with determination of the most appropriate temperature, the germination was tested in light absence. The germination percentage, the index of germination speed and medium time of germination were evaluated. For $R$. floccosa, the highest germination percentage was at $20{ }^{\circ} \mathrm{C}$. For $R$. pilocarpa and $R$. teres, the highest germination percentages occurred in $15^{\circ} \mathrm{C}$ and $20^{\circ} \mathrm{C}$. There was correlation to germination percentage between the three species, indicating that they had similar germination behavior. Total absence of germination was verified for the three species in condition of light absence. In conclusion, the temperature of $20^{\circ} \mathrm{C}$ is the most suitable for the seed germination of $R$. floccosa. For the species $R$. pilocarpa and $R$. teres, the temperatures of 15 and $20{ }^{\circ} \mathrm{C}$ are the most suitable.
\end{abstract}

Keywords: epiphytes, Brazilian cacti, Rhipsalis flocoosa, Rhipsalis pilocarpa, Rhipsalis teres.

\section{Caracterização física de frutos de Rhipsalis (Cactaceae) e germinação de sementes em diferentes regimes de temperatura e luz}

\begin{abstract}
Resumo
Existem poucos estudos sobre características germinativas de espécies de cactos nativos, sendo a temperatura e a luz, os fatores que mais interferem nesse processo. Assim, objetivou-se caracterizar os frutos e avaliar a influência da temperatura e luminosidade na germinação de sementes de Rhipsalis floccosa, Rhipsalis pilocarpa and Rhipsalis teres. Testou-se temperaturas constantes de $15,20,25,30$ e $35^{\circ} \mathrm{C}$ e alternadas de $20-30{ }^{\circ} \mathrm{C}$ e $25-35^{\circ} \mathrm{C}$ com fotoperíodo de 10 horas, e com a determinação da temperatura mais adequada, testou-se a germinação na ausência de luz. A porcentagem de germinação, o índice de velocidade de germinação e o tempo médio de germinação foram avaliados. Para $R$. floccosa, a maior porcentagem de germinação foi obtida a $20{ }^{\circ} \mathrm{C}$. Para $R$. pilocarpa e $R$. teres, as maiores porcentagens de germinação ocorreram a $15^{\circ} \mathrm{C}$ e $20^{\circ} \mathrm{C}$. Verificou-se correlação entre as três espécies para a porcentagem de germinação, indicando comportamento semelhante entre essas. Na ausência de luz não ocorreu a germinação das sementes das espécies estudas. Em conclusão, a temperatura de $20^{\circ} \mathrm{C}$ é a mais indicada para a germinação de sementes de $R$. floccosa. Para as espécies $R$. pilocarpa e $R$. teres, as temperaturas de 15 e $20^{\circ} \mathrm{C}$ são as mais indicadas.
\end{abstract}

Palavras-chave: epífitas, cactos brasileiros, Rhipsalis flocoosa, Rhipsalis pilocarpa, Rhipsalis teres.

\section{Introduction}

The genus Rhipsalis is consisted of epiphytes or rupicola cacti, with cylindrical or flattened phylloclade that can reach more than two meters long. The flowers are small, white or yellowish, with small, pulpy, white to reddish fruits and its seeds are dark, dipped into white or transparent mucilage (Paula and Ribeiro, 2004).

The species Rhipsalis floccosa occurs in the south and southeast of Brazil, in the states of Minas Gerais, Espírito

Santo, Rio de Janeiro, São Paulo, Paraná, Santa Catarina e Rio Grande do Sul, from the Atlantic coast to seasonal forests and can be found at up to 1,800 meters (Barthlott and Taylor, 1995). Rhipsalis pilocarpa are found from the Atlantic Forest in the state of Paraná to the state Espírito Santo. Due to the destruction of the Atlantic Forest and the collection for its exotic beauty, this species is becoming increasingly rare to be found in their natural environment. 
Rhipsalis teres is distributed in the states of Minas Gerais, Rio de Janeiro, São Paulo, Paraná, Santa Catarina e Rio Grande do Sul (Barthlott and Taylor, 1995). They are pendant plants, with cylindrical cladodes, green, up to $50 \mathrm{~cm}$ long (Bruxel and Jasper, 2005).

According to Paula and Ribeiro (2004), the time of germination of the seeds of cactaceae varies according to the species; it may be immediate or take up months. The epiphytic cacti usually have a faster germination, and, in some cases, the seeds start the germination inside the mature fruit, as also happen in some species of Disocactus. To Oliveira et al. (1989), little is known about germination characteristics of native species, representing less than $0.1 \%$ of prescriptions and recommendations of forests seeds in Regras para Análises de Sementes - RAS (Rules for Seed Analysis - RSA).

Studies about the influence of temperature in the germination of seeds are essential to understand the ecophysiological and biochemical aspects of that process (Labouriau, 1983; Bewley and Black, 1994). Its effects can be evaluated from changes caused in percentage, speed and frequency relative of germination over the time of incubation (Labouriau and Pacheco, 1978).

Light is necessary for germination of seeds of some species, which are called "positive photoblastic". The "negative photoblastic" are the ones that germinate better when there is limitation of light, there being also, the indifferent ones, which do not present light sensibility. The seeds of most crop plants germinate both in the presence or absence of light, although the non photoblastic seeds may require the presence of light in unfavorable environmental conditions. The classification of seeds concerning to the sensibility of light is important for the conducting of germination tests (Villiers, 1972; Mayer and Poljakoff-Mayber, 1989).

To Heydecker (1977), light and temperature are environmental factors of major importance in the promotion of seed germination, affecting the amount of germinated seeds and the speed of germination.

Based on those, the objective of this study was to characterize the fruits and assess the influence of temperature and light on the germination of three species of cacti from the genus Rhipsalis.

\section{Material and Methods}

Seeds of three species of epiphytic cacti were used; Rhipsalis floccosa Salm-Dyck ex Pfeiff., Rhipsalis pilocarpa Loefgr. e Rhipsalis teres (Weber) Barthlott \& Taylor. Seeds were collected from plants arrays existing in State University of Londrina (Paraná State) and from private collections in Londrina city, in August 2010. The fruits of three species were characterized in length $(\mathrm{cm})$, diameter $(\mathrm{cm})$ weight $(\mathrm{g})$, and number of seeds per fruit. After the characterization, the seeds were removed from the fruits, washed in running water and dried for a period of 24 hours for homogenization and subsequent cold storage $\left(10+1{ }^{\circ} \mathrm{C}\right.$ e $45+3 \%$ U.R.) for 30 days. After this period, the seeds were homogenized and characterized again in relation to the weight of 100 seeds (eight repetitions of 100 seeds for each species) and the humidity of seeds was determined. For this, four replicates of $1 \mathrm{~g}$ of seeds of each species were used, which were packed in metal capsules and placed to dry in an oven at $105^{\circ} \mathrm{C}( \pm 3)$ for 24 hours and then weighed on a precision balance.

After the characterization, the other seeds were homogenized again and spread on a sheet of blotting paper, in transparent plastic boxes with covers $(11 \times 11 \times 3.5 \mathrm{~cm})$. The plastic boxes were maintained in germinators at constant temperatures of $15,20,25,30$ and $35^{\circ} \mathrm{C}$ and alternating $20-25^{\circ} \mathrm{C}$ and $30-35^{\circ} \mathrm{C}$ and with a photoperiod of 10 hours with 1250 lux $\left(17.9 \mathrm{mmol} \mathrm{m}^{-2} \mathrm{~s}^{-1}\right)$ lighting. Before seeding, the paper filter was moistened with distilled water at a ratio of 2.5 times the weight of the paper. After wetting, 50 seeds were sown for a total of four boxes per box temperature. The experimental design was completely randomized in a $3 \times 7$ factorial (species $\times$ temperature), with four replicates per temperature for each species.

The evaluation of the germination test was performed daily for 30 days, being considered germinated the seeds that had root emission. After that evaluation, the seeds of the three species were tested for sensitivity to light. Four replications of 50 seeds for each species were used, packed in transparent plastic boxes the same way as mentioned above. The plastic boxes were covered with foil and placed inside two black plastic bags and kept in germinators in a temperature of $20^{\circ} \mathrm{C}$ (established by the previous experiment). Assessments were also performed daily for 30 days in a room equipped with a green light.

Germination tests evaluated the germination percentage, the index of germination rate (GSI), calculated according to the Maguire's formula (1962) described by Nakagawa (1994):

$$
G S I=(G 1 / N 1)+(G 2 / N 2)+\ldots+(G n / N n)
$$

where: $\mathrm{G} 1$ = number of germinated seeds in the first count; $\mathrm{N} 1=$ number of days until the first count; G2 = number of seeds germinated in the second count; $\mathrm{N} 2$ = number of days elapsed until the second count; $\mathrm{n}=$ last count, and the average time of germination (ATG - days) calculated according to Lima et al. (2006):

$$
A T G=\left(\sum n i t i\right) / \sum n i
$$

where: $\mathrm{ni}=$ number of germinated seeds per day; $\mathrm{t} i=$ incubation time; $\mathrm{i}=1 \rightarrow 30$ days. Unit: days.

For data on germination percentage transformation on arcsine was performed $(\mathrm{x} / 100) 0.5$. Data were subjected to analysis of variance and averages were compared by Tukey test at $5 \%$ probability. Correlations were made between variables and between species. Daily frequency of germination was also calculated. 


\section{Results}

In relation to the characterization of the fruit highest values for $R$. pilocarpa were observed, followed by $R$. floccosa and lastly $R$. teres, showing a decreasing order of size and weight of the fruit. That order is maintained for the number of seeds per fruit and weight of 100 seeds, where, in the latter, there is only a small difference between $R$. pilocarpa and R. floccosa. The average values of seed moisture were close, varying between $6.55 \%$ for $R$. teres to $7.61 \%$ for $R$. pilocarpa (Table 1 ).

In the germination test, the temperature of $20^{\circ} \mathrm{C}$ provided the highest percentage of germination for $R$. floccosa $(92 \%)$. For $R$. teres and $R$. pilocarpa temperatures of 15 and $20^{\circ} \mathrm{C}$ provided the highest germination percentages. Temperatures of 15 and $20{ }^{\circ} \mathrm{C}$ had the highest overall averages for the percentage of germination ( 70 and $72 \%$ respectively). The overall averages also showed that the

Table 1. Characterization of the fruits and seeds of Rhipsalis floccosa, R. pilocarpa and R. teres about the length (CF) (cm), diameter (DF) (cm), fresh weight of fruit (PF) (g), number of seeds per fruit (NS), 100 seed weight (PS) (g) and humidity of seeds (UM) (\%).

\begin{tabular}{ccccccc}
\hline Species & CF & DF & PF & NS & PS & UM \\
\hline R. floccosa & $0.65+0.08$ & $0.73+0.07$ & $0.220+0.060$ & $30+10.49$ & $0.03025+0.0004$ & $6.73+0.58$ \\
R. pilocarpa & $0.94+0.06$ & $0.88+0.07$ & $0.430+0.097$ & $72+18.89$ & $0.03212+0.0003$ & $7.61+0.23$ \\
R. teres & $0.47+0.05$ & $0.48+0.05$ & $0.063+0.015$ & $6+3.45$ & $0.00955+0.0006$ & $6.55+0.38$ \\
\hline
\end{tabular}

Table 2. Germination percentages, germination speed index (GSI) and average time of germination (ATG) (days) of seeds of Rhipsalis floccosa, R. teres and R. pilocarpa in different temperatures.

\begin{tabular}{|c|c|c|c|c|c|c|c|c|}
\hline \multicolumn{9}{|c|}{$\begin{array}{l}\text { Percentage of Germination } \\
\end{array}$} \\
\hline Temperatures $\left({ }^{\circ} \mathrm{C}\right)$ & \multicolumn{2}{|c|}{ R. floccose } & \multicolumn{2}{|c|}{ R. teres } & \multicolumn{2}{|c|}{ R. pilocarpa } & \multicolumn{2}{|c|}{ Averages } \\
\hline 15 & 76 & $\mathrm{Bb}^{*}$ & 41 & Ac & 93 & $\mathrm{Aa}$ & 70 & $\mathrm{~A}$ \\
\hline 20 & 92 & Aa & 36 & $\mathrm{Ab}$ & 89 & $\mathrm{Aa}$ & 72 & A \\
\hline 25 & 63 & $\mathrm{Ca}$ & 9 & $\mathrm{Bb}$ & 71 & $\mathrm{Ba}$ & 47 & $\mathrm{~B}$ \\
\hline 30 & 10 & $\mathrm{Ea}$ & 0 & $\mathrm{Bb}$ & 14 & $\mathrm{Da}$ & 8 & $\mathrm{DE}$ \\
\hline 35 & 5 & $\mathrm{Ea}$ & 0 & $\mathrm{Ba}$ & 3,5 & $\mathrm{Da}$ & 3 & $\mathrm{E}$ \\
\hline $20-30$ & 36 & $\mathrm{Da}$ & 4 & $\mathrm{Bb}$ & 33 & $\mathrm{Ca}$ & 24 & $\mathrm{C}$ \\
\hline $25-35$ & 25 & $\mathrm{Da}$ & 1 & $\mathrm{Bb}$ & 8 & $\mathrm{Db}$ & 11 & $\mathrm{D}$ \\
\hline Averages & 44 & $\mathrm{a}$ & 13 & $\mathrm{~b}$ & 45 & $\mathrm{a}$ & & \\
\hline C.V.(\%) & & & 16.68 & & & & & \\
\hline \multicolumn{9}{|c|}{ GSI } \\
\hline Temperatures $\left({ }^{\circ} \mathrm{C}\right)$ & \multicolumn{2}{|c|}{ R. floccose } & \multicolumn{2}{|c|}{ R. teres } & \multicolumn{2}{|c|}{ R. pilocarpa } & \multicolumn{2}{|c|}{ Averages } \\
\hline 15 & 4.69 & $\mathrm{Ba}$ & 1.26 & $\mathrm{Ac}$ & 3.00 & $\mathrm{Ab}$ & 2.98 & $\mathrm{~B}$ \\
\hline 20 & 10.80 & $\mathrm{Aa}$ & 1.60 & $\mathrm{Ac}$ & 3.43 & $\mathrm{Ab}$ & 5.28 & A \\
\hline 25 & 11.47 & $\mathrm{Aa}$ & 0.40 & $\mathrm{Ac}$ & 2.90 & $\mathrm{Ab}$ & 4.92 & A \\
\hline 30 & 0.77 & $\mathrm{Ca}$ & 0.00 & $\mathrm{Aa}$ & 0.36 & $\mathrm{Ba}$ & 0.38 & $\mathrm{D}$ \\
\hline 35 & 0.20 & $\mathrm{Ca}$ & 0.00 & $\mathrm{Aa}$ & 0.09 & $\mathrm{Ba}$ & 0.10 & $\mathrm{D}$ \\
\hline $20-30$ & 3.72 & $\mathrm{Ba}$ & 0.16 & $\mathrm{Ab}$ & 0.94 & $\mathrm{Bb}$ & 1.61 & $\mathrm{C}$ \\
\hline $25-35$ & 0.86 & $\mathrm{Ca}$ & 0.03 & $\mathrm{Aa}$ & 0.20 & $\mathrm{Ba}$ & 0.36 & $\mathrm{D}$ \\
\hline Averages & 4.64 & $\mathrm{a}$ & 0.49 & $\mathrm{c}$ & 1.56 & $\mathrm{~b}$ & & \\
\hline C.V.(\%) & & & 38.25 & & & & & \\
\hline \multicolumn{9}{|c|}{ ATG } \\
\hline Temperatures $\left({ }^{\circ} \mathrm{C}\right)$ & \multicolumn{2}{|c|}{ R. floccose } & \multicolumn{2}{|c|}{ R. teres } & \multicolumn{2}{|c|}{ R. pilocarpa } & \multicolumn{2}{|c|}{ Averages } \\
\hline 15 & 8.50 & $\mathrm{ABb}$ & 18.29 & $\mathrm{Aa}$ & 15.61 & $\mathrm{Aab}$ & 14.13 & $\mathrm{~A}$ \\
\hline 20 & 5.09 & $\mathrm{Bb}$ & 11.82 & $\mathrm{Aab}$ & 13.61 & $\mathrm{Aa}$ & 10.17 & A \\
\hline 25 & 4.86 & $\mathrm{Bb}$ & 11.67 & $\mathrm{Aab}$ & 13.63 & $\mathrm{Aa}$ & 10.05 & A \\
\hline 30 & 9.81 & $\mathrm{ABb}$ & 0.00 & $\mathrm{Bc}$ & 19.49 & $\mathrm{Aa}$ & 9.77 & A \\
\hline 35 & 13.75 & $\mathrm{ABa}$ & 0.00 & $\mathrm{Bb}$ & 14.40 & $\mathrm{Aa}$ & 9.38 & A \\
\hline $20-30$ & 8.59 & $\mathrm{ABb}$ & 14.38 & $\mathrm{Aab}$ & 18.65 & $\mathrm{Aa}$ & 13.87 & A \\
\hline $25-35$ & 16.09 & Aa & 9.50 & $\mathrm{Aa}$ & 15.47 & $\mathrm{Aa}$ & 13.68 & A \\
\hline Averages & 9.52 & $\mathrm{~b}$ & 9.38 & $\mathrm{~b}$ & 15.84 & $\mathrm{a}$ & & \\
\hline C.V.(\%) & & & 37.29 & & & & & \\
\hline
\end{tabular}

* Averages followed by the same letter, uppercase and lowercase in the column on the line, do not differ by Tukey test at $5 \%$ probability. 
germination of $R$. floccosa and R. pilocarpa was superior to the $R$. teres (Table 2).

In relation to GSI (Equation 1), temperatures of 20 and $25{ }^{\circ} \mathrm{C}$ yielded the highest values for R. floccosa (10.80 and 11.47 respectively). For $R$. pilocarpa temperatures of 15,20 and $25^{\circ} \mathrm{C}$ were more favorable, and for $R$. teres no statistical differences were found for this variable. According to the general averages, temperatures of 20 and $25^{\circ} \mathrm{C}$ provided the highest values of GSI (5.28 and 4.92 respectively), and $R$. floccosa GSI has a higher value (4.64) compared to other species, characterizing a faster germination.

The temperatures of 20 and $25^{\circ} \mathrm{C}$ showed low values of ATG (Equation 2) (characterizing faster germination) for $R$. floccosa (5.09 and 4.86 days, respectively), however, differing statistically only in temperature of $25-35{ }^{\circ} \mathrm{C}$ (16.09 days). For $R$. teres and $R$. pilocarpa there was no difference between the averages within the temperature that presented germination. The overall averages showed no differences in ATG between the temperatures. However, it was observed that $R$. floccos $a$ and $R$. teres showed lower values of ATG (9.52 and 9.38 days, respectively) relative to $R$. pilocarpa (15.84 days) (Table 2).

For the three species there was a significant and positive correlation between the percentage of germination and GSI, showing that the temperatures which influence negatively or positively the germination influence the GSI in the same way. However, there was no correlation between the percentage of germination and ATG and there was a significant negative correlation only in $R$. floccosa between GSI and ATG (Table 3).

The daily frequency polygon of germination shows that at $15^{\circ} \mathrm{C}$ there were two peaks of germination for R. floccosa, in the $9^{\text {th }}$ and $11^{\text {th }}$ day, with the germination starting on the $8^{\text {th }}$ day. There is also one large peak of germination for $R$. pilocarpa on day 14 , which had initiated germination on the $9^{\text {th }}$ day. For $R$. teres the frequency remained low and constant between $13^{\text {th }}$ and $26^{\text {th }}$ days (Figure 1).

At $20^{\circ} \mathrm{C}$ the germination of $R$. floccos $a$ and $R$. pilocarpa began on day 5 , and on day 6 for $R$. teres. R. floccosa germination peaked on day 6 and remained high until the $9^{\text {th }}$ day. $R$. pilocarpa presented the germination peak on day 14 . $R$. teres showed three small peaks of germination, on the $7^{\text {th }}, 9^{\text {th }}$, and $13^{\text {th }}$ day (Figure 1 ).
At $25^{\circ} \mathrm{C}$ the germination of $R$. floccosa began on the $4^{\text {th }}$ day, with peaks of germination in the $4^{\text {th }}$ and $7^{\text {th }}$ days. For $R$. teres and $R$. pilocarpa the germination began on the $5^{\text {th }}$ day, with peaks of germination in the $9^{\text {th }}$ and $11^{\text {th }}$ days for $R$. pilocarpa and daily germination below $5 \%$ for $R$. teres (Figure 1).

In temperatures of 30 and $35^{\circ} \mathrm{C}$ the daily germination was below $5 \%$ for all species, being null for $R$. teres. In the alternate $25-35^{\circ} \mathrm{C}$ just $R$. floccosa showed a small peak above $5 \%$ on the $20^{\text {th }}$ day. At $20-30{ }^{\circ} \mathrm{C}$ R. floccosa showed a peak of germination below $10 \%$ at $14^{\text {th }}$ day, and $R$. pilocarpa showed the peak $(5.5 \%)$ on day 20 . The daily frequency of $R$. teres remained below $5 \%$ during the whole period (Figure 1).

The end of germination varied between $14^{\text {th }}$ day $\left(20^{\circ} \mathrm{C}\right)$ until $26^{\text {th }}$ day $\left(15^{\circ} \mathrm{C}\right)$ to $R$. floccosa, between $20^{\text {th }}$ day $\left(25^{\circ} \mathrm{C}\right)$ until $26^{\text {th }}$ day $\left(15^{\circ} \mathrm{C}\right)$ to $R$. teres and also of $20^{\text {th }}\left(15\right.$ and $\left.35^{\circ} \mathrm{C}\right)$ until $26^{\text {th }}$ day $\left(25^{\circ} \mathrm{C}\right)$ to $R$. pilocarpa (Figure 1).

As to the light sensitivity test, there was complete absence of germination for the three species under the condition of absence of light (not tabulated) showing that the tested species are positive photoblastic.

\section{Discussion}

It was observed that higher temperatures $\left(30\right.$ and $\left.35^{\circ} \mathrm{C}\right)$ were not favorable for germination of either species evaluated. Thereby the alternated temperatures, for having elevated temperatures in its variation, were also not favorable for the germination of all the three species. It can be affirmed that the temperature of $30^{\circ} \mathrm{C}$ is limiting for the germination of $R$. teres, considering that at this temperature and above it $\left(35^{\circ} \mathrm{C}\right)$ there was not germination (Table 2$)$.

As observed in the percentage of germination, higher temperatures also showed low values of GSI for $R$. floccosa and $R$. pilocarpa (Table 2). According to Carvalho and Nakagawa (2000), germination is much faster and has a more efficient process, the higher the temperature, to a certain limit. Thus, germination only occurs within a certain temperature range; either above or below the upper and lower values, respectively, germination will not occur. Within these limits there is a temperature or temperature range at which the process occurs at maximum efficiency,

Table 3. Correlation ( $\mathrm{r}$ ) between germination percentages $(\% \mathrm{G})$, germination speed index $(\mathrm{GSI})$ and average germination time (ATG) for three species of Rhipsalis and between the species for the three previous variables.

\begin{tabular}{|c|c|c|c|}
\hline Species & $\% G \times G S I$ & $\%$ G ATG & GSI x ATG \\
\hline R. floccose & $0.85 *$ & $-0.74^{\mathrm{ns}}$ & $-0.87 *$ \\
\hline$R$. teres & $0.97 * *$ & $0.67^{\mathrm{ns}}$ & $0.61^{\mathrm{ns}}$ \\
\hline \multirow[t]{2}{*}{ R. pilocarpa } & $0.99 * *$ & $-0.43^{\mathrm{ns}}$ & $-0.52^{\mathrm{ns}}$ \\
\hline & $\% \mathrm{G}$ & GSI & ATG \\
\hline R. floccosa $\times R$. teres & $0.89 * *$ & $0.66^{\mathrm{ns}}$ & $-0.44^{\mathrm{ns}}$ \\
\hline R. floccosa $\times R$. pilocarpa & $0.97 * *$ & $0.89 * *$ & $0.18^{\mathrm{ns}}$ \\
\hline$R$. teres $\times R$. pilocarpa & $0.90 * *$ & $0.88 * *$ & $-0.20^{\mathrm{ns}}$ \\
\hline
\end{tabular}

* Significant at $5 \%$. ** Significant at $1 \%$. "ns" not significant by T test. 
that is, obtains the maximum germination in the shortest possible time.

It has been observed in several studies that the optimum temperature for seed germination of cacti is usually around $25^{\circ} \mathrm{C}$ (Nobel, 1988; Rojas-Aréchiga and Vázquez-Yanes,

$15^{\circ} \mathrm{C}$

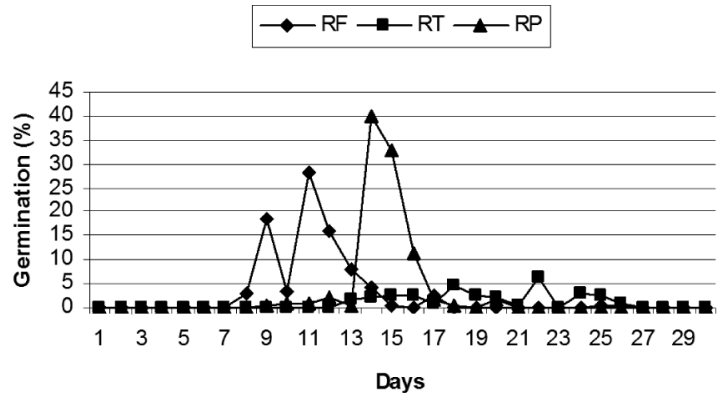

$25^{\circ} \mathrm{C}$

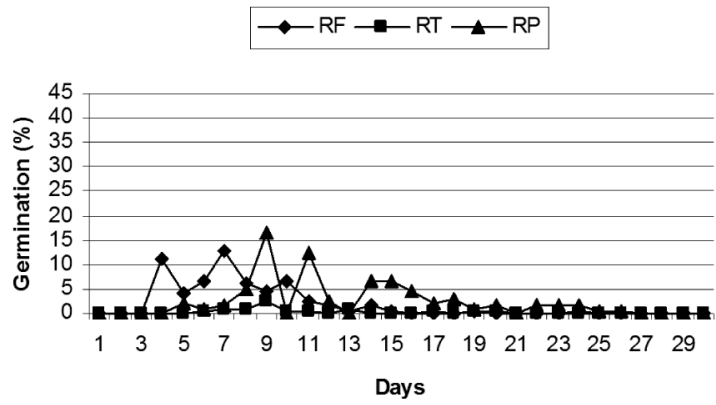

${ }^{35^{\circ} \mathrm{C}}$

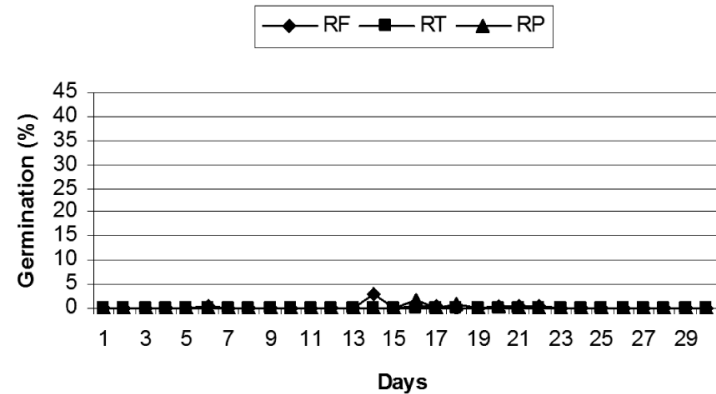

2000; Lone et al., 2007), although in this study it was found that the lowest temperatures of $15{ }^{\circ} \mathrm{C}$ and $20{ }^{\circ} \mathrm{C}$ were those that showed the highest percentage of germination, similar results was verified in Hylocereus setaceus seeds germination (Simão et al., 2010). These results are probably

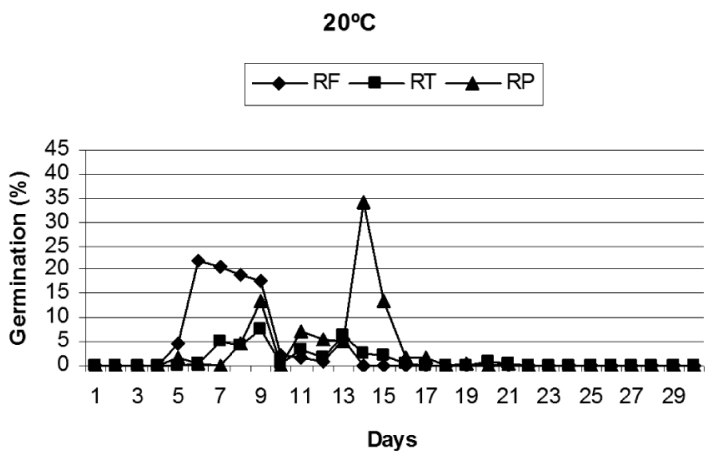

$30^{\circ} \mathrm{C}$

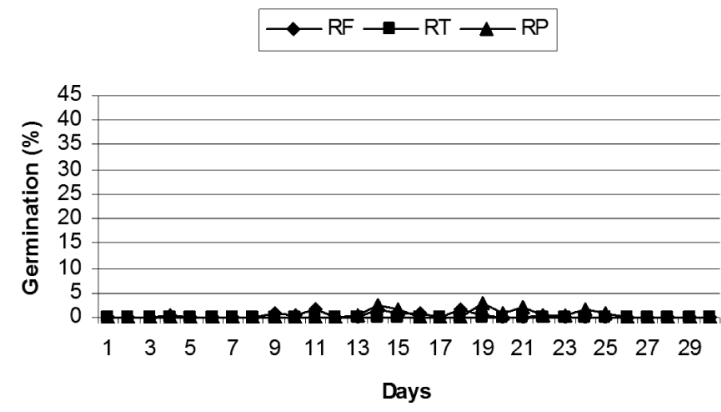

$20-30^{\circ} \mathrm{C}$
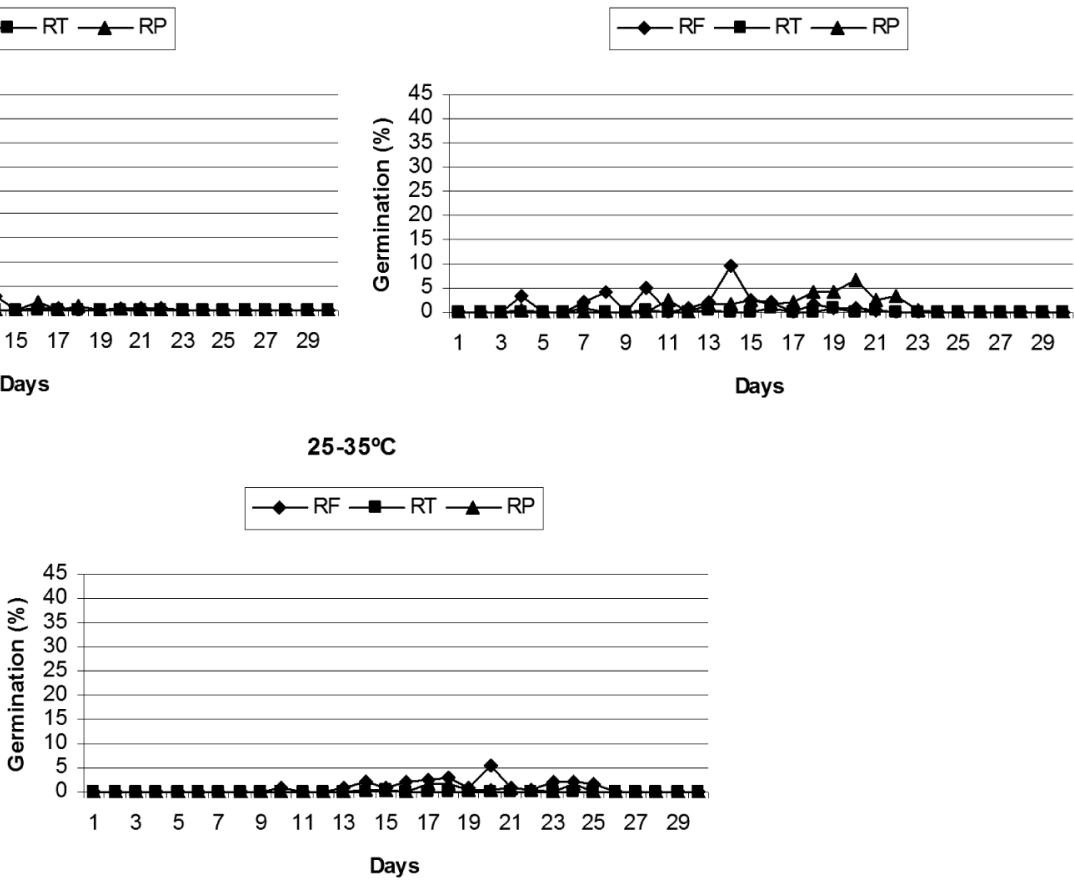

Figure 1. Daily frequency of germination (\%) of Rhipsalis floccosa (RF), R. teres (RT) and R. pilocarpa (RP) at different temperatures. 
related to the epiphytic habit of the three species. In a study of epiphytic (Bromeliaceae, Orchidaceae e Cactaceae) in the Reserva do Parque do Zizo, São Miguel Arcanjo, São Paulo, França (2003), found that an increased occurrence of epiphytic was in places that had temperatures between 18 and $21^{\circ} \mathrm{C}$.

Lone et al. (2010) evaluated the germination of epiphytic cactus Schlumbergera truncata and concluded that a temperature of $20{ }^{\circ} \mathrm{C}$ was the most suitable for germination of this species. Also according to the authors, the temperature of $30^{\circ} \mathrm{C}$ was not favorable for germination percentage, for the GSI and ATG of this species, as observed in this study. However, Simão et al. (2007) found that the optimum temperature for germination of epiphytic cactus Hylocereus setaceus is between 25 and $30^{\circ} \mathrm{C}$. However, this species does not have only the epiphytic habit. According to Junqueira et al. (2002), this species can develop in rock masses and in sandy soils, environments that differ from the environment where epiphytes grow normally.

High significant correlation values for germination percentage among the three species have been observed, indicating that they had similar germination behavior at different temperatures. For the GSI, there was no significant correlation between $R$. floccosa and $R$. teres. For the ATG there was no significant correlation between species (Table 3 ).

In relation of daily frequency of germination, similar results were obtained by Lone et al. (2010), with the cactus epiphyte Schlumbergera truncata, where the onset of germination was observed between the $5^{\text {th }}$ (temperatures of 20 and $25^{\circ} \mathrm{C}$ ) and $7^{\text {th }}$ days $\left(30^{\circ} \mathrm{C}\right)$, with the end of germination between 22 (to $20^{\circ} \mathrm{C}$ ) to 26 days (at $30^{\circ} \mathrm{C}$ ). The germination behavior similar for different species of cacti can be related to the common epiphytic habit shared by them.

The three tested species showed be positive photoblastic. According to Takaki et al. (1985), positive photoblastic seeds could be characterized by requiring a high threshold of phytochrome far-red (Pfr), to germinate, existing within the seed Pfr in an insufficient amount to start the germination process. Thus, an exposure to light for a period of time is necessary to reach a satisfactory amount for the beginning of germination. Rebouças and Santos (2007) also found no germination of seeds of Melocactus conoideus (Cactaceae) in the absence of light. The absence of germination in the dark was also evidenced by Ortega-Baes and Rojas-Arechiga (2007) for Trichocereus terscheckii (Cactaceae). However, Pedroni and Sánchez (1997) obtained germination indifferent to light in a wide range of temperatures in Pereskia aculeata (Cactaceae). It shows that there is a broad germinating behavior inside the cacti in relation to light.

For the epiphytic cacti evaluated in this study the milder temperatures (below $25^{\circ} \mathrm{C}$ ) favored germination, possibly because they are adapted to the shaded forest, however, the seeds need a certain amount of light, because in an environment with total absence of light seeds do not germinate.
It is concluded that $R$. pilocarpa has larger fruits with more, and heavier, seeds, followed by $R$. floccosa and lastly $R$. teres. We further conclude that the temperature of $20^{\circ} \mathrm{C}$ is the most suitable for the germination of $R$. flocoosa. For the species $R$. pilocarpa and $R$. teres, temperatures of 15 and $20^{\circ} \mathrm{C}$ are the most indicated. The temperatures of 30 and $35^{\circ} \mathrm{C}$ were not favorable for the germination of the three species. The three species assessed proved to be positive photoblastic, requiring light for seed germination to occur.

\section{References}

BARTHLOTT, W. and TAYLOR, N.P., 1995. Notes towards a monograph of Rhipsalideae (Cactaceae). Bradleya, vol. 13, pp. 43-79.

BEWLEY, J.D. and BLACK, M., 1994. Seeds: physiology of development and germination. 3rd ed. New York: Plenum Press. http://dx.doi.org/10.1007/978-1-4899-1002-8.

BRUXEL, J. and JASPER, A., 2005. A família Cactaceae na Bacia Hidrográfica do Rio Taquari, RS, Brasil. Acta Botanica Brasílica, vol. 19, no. 1, pp. 71-79. http://dx.doi.org/10.1590/ S0102-33062005000100008.

CARVALHO, N.M. and NAKAGAWA, J., 2000. Sementes: ciência, tecnologia e produção. 4th ed. Jaboticabal: Funep.

FRANÇA, V.B., 2003. Dados preliminares sobre o estudo das epifitas (Bromeliaceae, Orchidaceae e Cactaceae) que ocorrem na Reserva do Parque do Zizo - São Miguel Arcanjo. Itú: Centro Universitário Nossa Senhora do Patrocínio. Relatório de conclusão do Bacharelado em Ciências Biológicas.

HEYDECKER, W., 1977. Stress and seed germination: na agronomic view. In: A. KHAN, ed. The physiology and biochemistry of seed dormancy and germination. Amesterdam: Elsevier.

JUNQUEIRA, K.P., JUNQUEIRA, N.T.V., RAMOS, J.D. and PEREIRA, A.V., 2002. Informações preliminares sobre uma espécie de pitaya do cerrado. Planaltina: EMBRAPA.

LABOURIAU, L.G. and PACHECO, A., 1978. On the frequency of isothermal germination in seeds of Dolichos biflorus L. Plant \& Cell Physiology, vol. 19, pp. 507-512.

LABOURIAU, L.G., 1983. A germinação de sementes. 1st ed. Washington: OEA.

LIMA, J.D., ALMEIDA, C.C., DANTAS, V.A.V., SILVA, B.M. and MORAES, W.S., 2006. Efeito da temperatura e do substrato na germinação de sementes de Caesalpinia ferrea Mart. ex Tul. (Leguminosae, Caesalpinoideae). Revista Árvore, vol. 30, no. 4, pp. 513-518. http://dx.doi.org/10.1590/S0100-67622006000400003.

LONE, A.B., SOUZA, G.R.B., OLIVEIRA, K.S., TAKAHASHI, L.A.S. and FARIA, R.T., 2010. Temperatura e substrato para germinação de sementes de flor-de maio (Schlumbergera truncata (Haw.) Moran). Revista Ceres, vol. 57, no. 3, pp. 367-371. http:// dx.doi.org/10.1590/S0034-737X2010000300012.

LONE, A.B., TAKAHASHI, L.S.A., FARIA, R.T. and UNEMOTO, L.K., 2007. Germinação de Melocactus bahiensis (cactaceae) em diferentes substratos e temperaturas. Scientia Agraria, vol. 8, no. 4, pp. 365-369. http://dx.doi.org/10.5380/rsa.v8i4.9881.

MAYER, A.C. and POLJAKOFF-MAYBER, A., 1989. The germination of seeds. 1st ed. London: Pergamon Press. 
NAKAGAWA, J., 1994. Testes de vigor baseados na avaliação das plântulas. In: R.D. VIEIRA and N.M. CARVALHO, eds. Testes de vigor em sementes. Jaboticabal: Funep.

NOBEL, P.S., 1988. Environmental biology of agaves and cacti. 1st ed. New York: Cambridge University Press.

OLIVEIRA, E.C., PIÑA-RODRIGUES, F.C.M. and FIGLIOLIA, M.B., 1989. Propostas para padronização de metodologias em análise de sementes florestais. Revista Brasileira de Sementes, vol. 11, no. 1, pp. 1-42. http://dx.doi.org/10.17801/0101-3122/ rbs.v11n1p1-42.

ORTEGA-BAES, P. and ROJAS-ARÉCHIGA, M., 2007. Seed germination of Trichocereus terscheckii (Cactaceae): Light, temperature and gibberellic acid effects. Journal of Arid Environments, vol. 69, no. 1, pp. 169-176. http://dx.doi. org/10.1016/j.jaridenv.2006.09.009.

PAULA, C.C. and RIBEIRO, O.B.C., 2004. Cultivo prático de cactáceas. 1st ed. Viçosa: UFV.

PEDRONI, F. and SÁNCHEZ, M., 1997. Dispersão de sementes de Pereskia aculeata Muller (Cactaceae) num fragmento florestal no sudeste do Brasil. Revista Brasileira de Biologia $=$. Brazilian Journal of Biology $=$ Revista Brasileira de Biologia, vol. 57, pp. 479-486.

REBOUÇAS, A.C.M.N. and SANTOS, D.L., 2007. Influência do fotoperíodo e qualidade de luz na germinação de sementes de Melocactus conoideus (Cactaceae). Revista Brasileira de Biociências, vol. 5, pp. 900-902.

ROJAS-ARÉCHIGA, M. and VÁZQUEZ-YANES, C., 2000. Cactus seed germination: a review. Journal of Arid Environments, vol. 44, no. 1, pp. 85-104. http://dx.doi.org/10.1006/jare.1999.0582.

SIMÃO, E., SOCOLOWSKI, F. and TAKAKI, M., 2007. The epiphytic cactaceae Hylocereus setaceus (Salm-Dick ex DC.) ralf bauer seed germination is controlled by light and temperature. Brazilian Archives of Biology and Technology, vol. 50, no. 4, pp. 655-662. http://dx.doi.org/10.1590/S1516-89132007000400011.

SIMÃO, E., TAKAKI, M. and CARDOSO, V.J.M., 2010. Germination response of Hylocereus setaceus (Salm-Dyck ex DC.) Ralf Bauer (Cactaceae) seeds to temperature and reduced water potentials. Brazilian Journal of Biology $=$ Revista Brasileira de Biologia, vol. 70, no. 1, pp. 135-144. http://dx.doi.org/10.1590/ S1519-69842010000100019. PMid:20231970.

TAKAKI, M., HEERINGA, G.H., CONE, J.W. and KENDRICK, R.E., 1985. Analysis of the effect light and temperature on the fluence response curves for germination of Rumex obtusifolius. Plant Physiology, vol. 77, no. 3, pp. 731-734. http://dx.doi. org/10.1104/pp.77.3.731. PMid:16664125.

VILLIERS, T.A., 1972. Seed dormancy. In: T.T. KOZLOWSKI, ed. Seed biology. New York: Academic Press. 